The University of Maine

DigitalCommons@UMaine

Earth Science Faculty Scholarship

Earth Sciences

8-20-1996

\title{
Chemical Species Spatial Distribution and Relationship to Elevation and Snow Accumulation Rate over the Greenland Ice Sheet
}

Q. Yang

Paul Andrew Mayewski

University of Maine, paul.mayewski@maine.edu

E. Linder

S. Whitlow

M. Twickler

Follow this and additional works at: https://digitalcommons.library.umaine.edu/ers_facpub

Part of the Atmospheric Sciences Commons, Climate Commons, Geochemistry Commons, Glaciology Commons, and the Hydrology Commons

\section{Repository Citation}

Yang, Q.; Mayewski, Paul Andrew; Linder, E.; Whitlow, S.; and Twickler, M., "Chemical Species Spatial Distribution and Relationship to Elevation and Snow Accumulation Rate over the Greenland Ice Sheet" (1996). Earth Science Faculty Scholarship. 240.

https://digitalcommons.library.umaine.edu/ers_facpub/240

This Article is brought to you for free and open access by DigitalCommons@UMaine. It has been accepted for inclusion in Earth Science Faculty Scholarship by an authorized administrator of DigitalCommons@UMaine. For more information, please contact

um.library.technical.services@maine.edu. 


\title{
Chemical species spatial distribution and relationship to elevation and snow accumulation rate over the Greenland Ice Sheet
}

\author{
Q. Yang, ${ }^{1}$ P. A. Mayewski, ${ }^{1}$ E. Linder, ${ }^{2}$ S. Whitlow, ${ }^{1}$ and M. Twickler ${ }^{1}$
}

\begin{abstract}
Major chemical species $\left(\mathrm{Cl}^{-}, \mathrm{NO}_{3}^{-}, \mathrm{SO}_{4}^{2-}, \mathrm{Na}^{+}, \mathrm{K}^{+}, \mathrm{Mg}^{2+}, \mathrm{Ca}^{2+}\right)$ from 24 snowpits (sampled at a resolution of $3 \mathrm{~cm}$, total 2995 samples) collected from northern, central, and southern Greenland were used for this investigation. The annual and seasonal (winter and summer) concentration of each chemical species was calculated and used to study the spatial distribution of chemical species over the central portion of the Greenland Ice Sheet. A two-sided $t$-distribution test $(\alpha=0.05)$ suggests that concentrations of major chemical species in snow do not vary significantly over this portion of central Greenland. The relationship between chemical concentration and snow accumulation rate was investigated using annual data from two groups of snowpits: those from coastal sites (northern and southern Greenland); and those from high-altitude inland sites (central Greenland). The snowpit data from a single group, when examined independently of the other group, show that chemical concentrations do not vary with snow accumulation rate. However, when data from the two groups are integrated into a single data set, pseudorelationships appear, with $\mathrm{NO}_{3}^{-}$concentration decreasing and $\mathrm{Na}^{+}, \mathrm{K}^{+}$, $\mathrm{Mg}^{2+}$, and $\mathrm{Cl}^{-}$increasing as snow accumulation rate increases. Therefore we suggest that it is improper to study the relationship between chemical concentration and snow accumulation rate by using data collected from different geographic sites. The relationship between elevation and chemical concentration was investigated using the same suite of annual data sets. We find that $\mathrm{Cl}^{-}, \mathrm{Na}^{+}$, and $\mathrm{Mg}^{2+}$ concentrations decrease, while $\mathrm{NO}_{3}^{-}$concentration increases, with increasing elevation on the Greenland Ice Sheet.
\end{abstract}

\section{Introduction}

Ice cores are an important tool for reconstructing past climatic and environmental change, and investigation of variations in chemical concentration snow and ice plays an important role in the interpretation of resultant records. In general, the concentration of a given chemical species in snow is determined by its sources, transportation pathways, and scavenging processes. For example, chemical species with marine sources tend to decrease with elevation in Greenland snow [Herron, 1982; Osada and Langway, 1993]. Gaseous species, such as $\mathrm{HNO}_{3}$ and $\mathrm{H}_{2} \mathrm{O}_{2}$, which are strongly influenced by atmospheric photochemistry, have significant postdepositional exchange between snow/firn and the atmosphere [Mayewski and Legrand, 1990; Bales and Wolf, 1995; Wolff, 1995; Yang et al., 1995]. Many of these influen-

\footnotetext{
${ }^{1}$ Glacier Research Group, Institute for the Study of Earth, Oceans and Space, University of New Hampshire, Durham.

${ }^{2}$ Mathematics Department, University of New Hampshire, Durham.

Copyright 1996 by the American Geophysical Union.
}

Paper number 96JD01061.

0148-0227/96/96JD-01061\$09.00 tial factors operate together; thus it is difficult to distinguish which is the controlling factor for the resultant chemical concentration in snow.

Previous studies of the spatial distribution of major cations and anions in Greenland snow have only been conducted on a regional basis [Mayewski et al., 1987; 1990; Davidson et al., 1989], while other studies have only focused on selected sections of ice cores from Greenland [Herron, 1982; Steffensen, 1988; Osada and Langway, 1993]. Notably, Herron [1982] and Osada and Langway [1993] used several ice cores of different ages from Greenland to suggest that concentrations of nitrate and non-sea-salt sulfate have a linear relationship to snow accumulation rate. However, Yang et al. [1995] reported that the chemical concentration of the major ions in central Greenland snow and ice demonstrate no predictable relationship to snow accumulation rate. The discrepancy may be because Herron [1982] and Osada and Langway [1993] used data from different ice core sites covering different time periods, while Yang et al. [1995] used continuous ice core data covering the last hundred years from a single location.

Understanding the spatial distribution and factors which affect chemical concentrations over the Greenland Ice Sheet can improve our ability to interpret the representativeness of detailed, single-site studies like the 
Greenland Ice Sheet Project 2 (GISP2) ice core. With snowpits at different locations but covering the same period, we are able in this study (1) to statistically examine chemical species spatial distribution on a yearby-year basis, (2) to investigate the relationship between chemical concentration and elevation, and (3) to reevaluate the relationship between snow accumulation rate and chemical concentrations over the Greenland Ice Sheet.

\section{Methodology}

Data retrieved from 24 snowpits were used in this investigation (Figure 1, Table 1). All snow pits in this study were sampled at a resolution of $3 \mathrm{~cm}$ (except for the 1990-ATM (see Figure 1) pit which was sampled at 5-cm intervals). To reduce significantly the possibility of sample contamination, all sampling tools and sample containers were precleaned using ultrapure water. During sampling, all personnel wore polyethylene gloves, nonparticulating clean suits, and masks. All samples were maintained frozen (in the field and during transportation to our laboratory) until analysis.

Measurements of the major anions and cations were performed by ion chromatography on a Dionex 4000 series instrument. Details of the technique are available in Whitlow et al. [1992].
The 3-cm sampling interval provides a high-resolution record (>12 samples per year) sufficient to document subseasonal inputs. Snowpit dating is based on oxygen isotope $\left(\delta^{18} \mathrm{O}\right)$ seasonal variations [Dansgaard et al., 1973]. Oxygen isotope values for 1987 snowpits were provided by the Isotope Laboratory in Copenhagen [Mayewski et al., 1990]. The rest of the oxygen isotope analyses were performed at the University of Washington. When the $\delta^{18} \mathrm{O}$ data were not available or did not provide a clear seasonal cycle, seasonal signals in hydrogen peroxide $\left(\mathrm{H}_{2} \mathrm{O}_{2}\right)$ [Sigg and Neftel, 1988] or the ratio between chloride and sodium $(\mathrm{Cl} / \mathrm{Na})$ [Whitlow et al., 1992] were utilized.

Mean annual chemical concentration of each year was calculated by averaging all sample concentrations between two adjacent summer peaks. Because of the subseasonal sampling resolution we were able to calculate the seasonal concentrations of chemical species in each snowpit. For this purpose we identify the inflection points on the roughly sinusoidal annual oscillation of $\delta^{18} \mathrm{O}$. Summer is taken to be all samples with $\delta^{18} \mathrm{O}$ values higher (less negative) than the inflection points for each year. Winter is the other part of the $\delta^{18} \mathrm{O}$ curve. Non-sea-salt chemical concentrations were calculated using $\mathrm{Na}^{+}$as the conservative marine source indicator [Legrand and Delmas, 1988; Mayewski et al., 1990; Whitlow et al., 1992]. Depth and period covered in each snowpit are presented in Table 1.

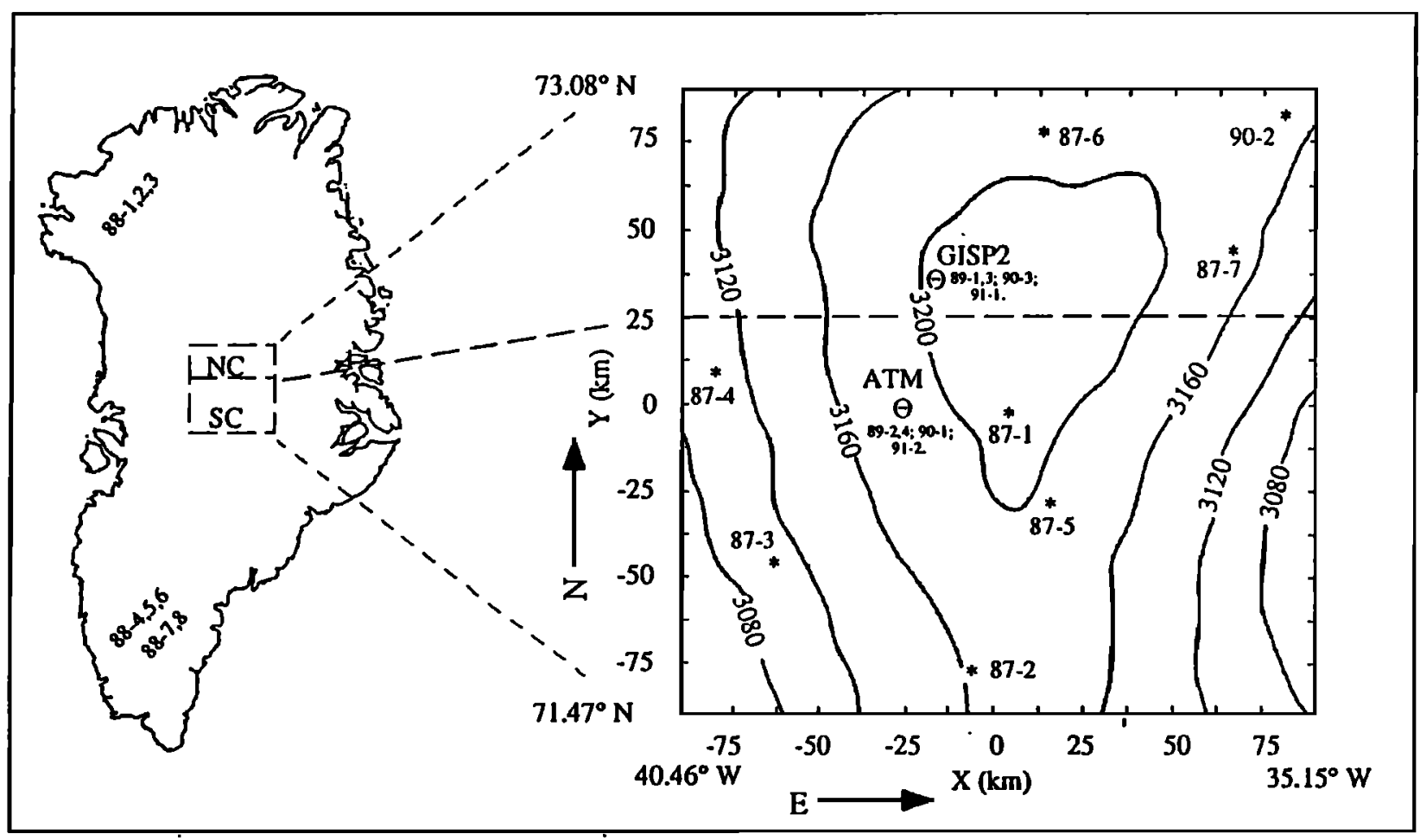

Legend

NC: north central Greenland; SC: south central Greenland; GISP2: Greenland Ice Core Project Two main camp (1989-1994); ATM: Atmospheric sampling site; *: snowpit site.

Figure 1. Location map of Greenland snowpits. Legend: NC, north central Greenland; SC, south central Greenland; GISP2, Greenland Ice Sheet Project 2 main camp (1989-1994); ATM, atmospheric sampling site; asterisk, snowpit site. 
Table 1. Snowpit Information

\begin{tabular}{|c|c|c|c|c|c|c|}
\hline $\begin{array}{l}\text { Snowpit } \\
\text { Year }\end{array}$ & $\begin{array}{l}\text { Location, } \\
\text { Lat., Long. }\end{array}$ & $\begin{array}{l}\text { Depth, } \\
\text { m }\end{array}$ & $\begin{array}{l}\text { Number of } \\
\text { Samples }\end{array}$ & $\begin{array}{c}\text { Time Period } \\
\text { Covered (yr A.D.) }\end{array}$ & $\begin{array}{l}\text { Elevation, } \\
\text { asl } \mathrm{m}\end{array}$ & $\begin{array}{r}\text { Mean Accuracy } \\
\text { Rate, } \mathrm{kg} \mathrm{m}^{-2} \mathrm{yr}^{-1}\end{array}$ \\
\hline \multicolumn{7}{|c|}{ Northern Greenland } \\
\hline $1988-1$ & $77.30^{\circ} \mathrm{N}, 60.60^{\circ} \mathrm{W}$ & 6.05 & 201 & 1981-1987 & 1850 & 293.1 \\
\hline $1988-2$ & $77.30^{\circ} \mathrm{N}, 59.20^{\circ} \mathrm{W}$ & 3.74 & 124 & $1984-1987$ & 1900 & 309.2 \\
\hline 1988-3 & $77.75^{\circ} \mathrm{N}, 59.55^{\circ} \mathrm{W}$ & 2.00 & 66 & $1986-1987$ & 1900 & 254.3 \\
\hline \multicolumn{7}{|c|}{ Central Greenland } \\
\hline 1987-1 & $72.24^{\circ} \mathrm{N}, 37.67^{\circ} \mathrm{W}$ & 6.00 & 200 & 1977-1986 & 3200 & 221.9 \\
\hline $1987-2$ & $71.57^{\circ} \mathrm{N}, 38.0^{\circ} \mathrm{W}$ & 4.04 & 134 & $1982-1986$ & 3160 & 249.4 \\
\hline $1987-3$ & $71.86^{\circ} \mathrm{N}, 39.66^{\circ} \mathrm{W}$ & 2.00 & 66 & $1985-1986$ & 3100 & 298.4 \\
\hline $1987-4$ & $72.35^{\circ} \mathrm{N}, 40.2^{\circ} \mathrm{W}$ & 4.00 & 133 & $1982-1986$ & 3100 & 267.1 \\
\hline $1987-5$ & $72.02^{\circ} \mathrm{N}, 37.28^{\circ} \mathrm{W}$ & 4.04 & 134 & 1981-1986 & 3190 & 221.5 \\
\hline $1987-6$ & $72.95^{\circ} \mathrm{N}, 37.41^{\circ} \mathrm{W}$ & 4.04 & 134 & $1979-1986$ & 3180 & 168.9 \\
\hline $1987-7$ & $72.65^{\circ} \mathrm{N}, 35.28^{\circ} \mathrm{W}$ & 4.04 & 134 & $1979-1986$ & 3170 & 175.8 \\
\hline $1989-1$ & $72.6^{\circ} \mathrm{N}, 38.5^{\circ} \mathrm{W}$ & 4.02 & 157 & $1983-1988$ & 3200 & 219.1 \\
\hline $1989-2$ & $72.32^{\circ} \mathrm{N}, 38.8^{\circ} \mathrm{W}$ & 4.02 & 157 & $1984-1988$ & 3190 & 241.2 \\
\hline 1989-3 & $72.6^{\circ} \mathrm{N}, 38.5^{\circ} \mathrm{W}$ & 2.01 & 67 & $1987-1988$ & 3200 & 189.2 \\
\hline $1989-4$ & $72.32^{\circ} \mathrm{N}, 38.8^{\circ} \mathrm{W}$ & 2.04 & 68 & $1986-1988$ & 3190 & 244.2 \\
\hline $1990-1$ & $72.32^{\circ} \mathrm{N}, 38.8^{\circ} \mathrm{W}$ & 6.00 & 120 & 1981-1989 & 3190 & 235.3 \\
\hline $1990-2$ & $72.98^{\circ} \mathrm{N}, 35.28^{\circ} \mathrm{W}$ & 4.05 & 135 & $1983-1989$ & 3170 & 172.1 \\
\hline 1990-3 & $72.6^{\circ} \mathrm{N}, 38.5^{\circ} \mathrm{W}$ & 4.10 & 135 & 1984-1989 & 3200 & 213.8 \\
\hline 1991-1 & $72.6^{\circ} \mathrm{N}, 38.5^{\circ} \mathrm{W}$ & 2.25 & 75 & 1989-1990 & 3200 & 207.8 \\
\hline 1991-2 & $72.32^{\circ} \mathrm{N}, 38.8^{\circ} \mathrm{W}$ & 2.16 & 72 & $1988-1990$ & 3190 & 252.4 \\
\hline \multicolumn{7}{|c|}{ Southern Greenland } \\
\hline $1988-4$ & $66.72^{\circ} \mathrm{N}, 45.49^{\circ} \mathrm{W}$ & 2.05 & 68 & 1986-1987 & 2200 & 300.1 \\
\hline $1988-5$ & $67.07^{\circ} \mathrm{N}, 45.57^{\circ} \mathrm{W}$ & 4.00 & 134 & 1984-1987 & 2300 & 332.6 \\
\hline $1988-6$ & $67.34^{\circ} \mathrm{N}, 43.79^{\circ} \mathrm{W}$ & 6.18 & 205 & $1982-1987$ & 2400 & 361.5 \\
\hline 1988-7 & $64.79^{\circ} \mathrm{N}, 44.29^{\circ} \mathrm{W}$ & 4.20 & 140 & $1985-1987$ & 2800 & 384.3 \\
\hline $1988-8$ & $65.64^{\circ} \mathrm{N}, 43.70^{\circ} \mathrm{W}$ & 4.10 & 136 & $1986-1987$ & 2600 & 566.8 \\
\hline
\end{tabular}

\section{Results and Discussion}

\section{Chemical Species Spatial Distribution}

Chemical records from the 16 snowpits in central Greenland were examined to see if mean annual chemical concentrations are statistically homogeneous. Snowpits in central Greenland were divided into north central (NC) and south central (SC) (Figure 1). The mean annual concentrations and standard errors for the concentrations of $\mathrm{Cl}^{-}, \mathrm{NO}_{3}^{-}, \mathrm{SO}_{4}^{2-}, \mathrm{Na}^{+}, \mathrm{K}^{+}, \mathrm{Mg}^{2+}, \mathrm{Ca}^{2+}$ between NC and SC are presented in Table 2a. Since the variance within the two groups are not the same, a two-sided $t$-distribution test [Microsoft Corporation, 1992] with unequal variances was applied. A minimum of four snowpits are required in each group for this test. Hence it is clear from Table 1 that only three years $(1984,1985$, and 1986) were suitable for testing. For all species and all years, a two-sided $t$-test $(\alpha=0.05)$ shows no significant difference between the two groups.

The same statistical method was applied to the mean winter and summer concentrations of the species from $\mathrm{NC}$ and SC (Table 2b). Again, no significant difference between the groups was found. The two-sided $t$ distribution test was also conducted between concentra- tions of chemical species from central and south Greenland for 1986 and 1987 (Table 2c). The $t$-test results suggest that concentrations of $\mathrm{NO}_{3}^{-}, \mathrm{SO}_{4}^{2-}, \mathrm{Ca}^{2+}$, and $\mathrm{K}^{+}$are statistically similar between the regions in 1986 and 1987. Higher concentrations of $\mathrm{Cl}^{-}, \mathrm{Na}^{+}$, and $\mathrm{Mg}^{2+}$ in southern Greenland (Table $2 \mathrm{c}$ ) than in central Greenland are statistically significant. We believe these differences are due to marine source proximity and elevation effect (Table 1).

However, it is apparent from Table 2 that variance in chemical concentrations within the groups is large. A recent surface snow chemistry spatial distribution survey conducted at the ATM station (Figure 1) shows that annual and seasonal chemical concentration under certain conditions can vary by as much as $30-40 \%$ on spatial scales of a few tens of centimeters [ $D i b b, 1996]$. It is believed that such variations may be caused by physical or chemical processing while snow falls onto the glacier surface. The mechanisms of this process are not well understood yet. However, previous studies [Steffensen, 1988; Mayewski et al., 1990] and our test results suggest that the GISP2 ice core chemical series record is representative of the annual and subannual glaciochemical signal for the central Greenland region. The small-scale temporal and spatial variation is averaged out and has 


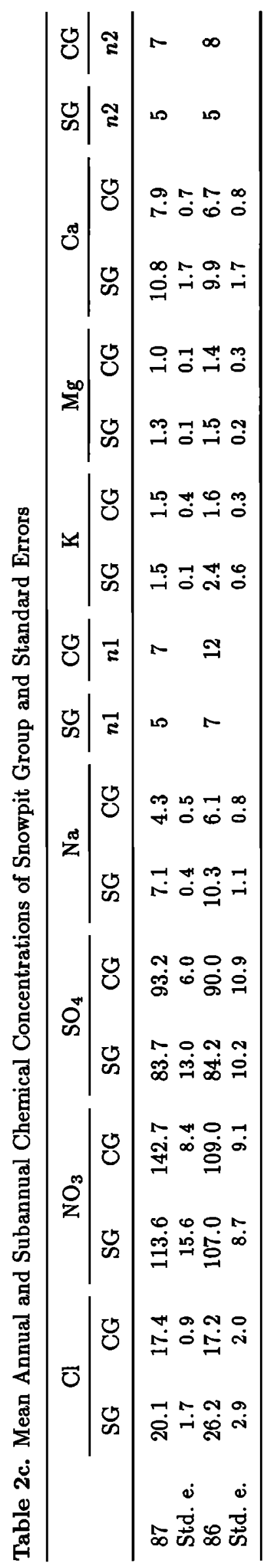

less impact on the mean annual and subannual chemical concentration in central Greenland.

\section{Elevation Versus Chemical Species}

Marine sea salt is believed to be a major source for $\mathrm{Na}^{+}$and $\mathrm{Cl}^{-}$observed in Greenland snow [Herron, 1982; Mayewski et al., 1984; 1990; Steffensen, 1988]. Changes in elevation can cause changes in sea-salt concentrations in snow because sea-salt aerosols are preferentially precipitated during air mass movement to higher altitudes. The locations of snowpits in this paper (Figure 1, Table 1) cover a range of 1850 to 3200 $\mathrm{m}$ above sea level. This allows investigation of the relationship between chemical species concentration and elevation using annual data sets.

Annual concentration of the major chemical species for the period 1984-1987 were generated from each snowpit and plotted against elevation (Figure 2). Since the snowpits cover different time periods (Table 1), the number of data points varies with elevation. Figure 2 shows that annual concentrations of $\mathrm{Na}^{+}, \mathrm{Cl}^{-}$, and $\mathrm{Mg}^{2+}$ decrease, while $\mathrm{NO}_{3}^{-}$concentration increases, with increasing elevation.

The trends for $\mathrm{Na}^{+}$and $\mathrm{Cl}^{-}$in this study agree with those previously reported by Herron [1982] and Legrand and Delmas [1988]. To explain the similar trend of $\mathrm{Mg}^{2+}$, we calculated mean annual non-sea-salt concentrations of $\mathrm{Cl}^{-}, \mathrm{Mg}^{2+}, \mathrm{Ca}^{2+}, \mathrm{K}^{+}$, and $\mathrm{SO}_{4}^{2-}$ for all snowpits using $\mathrm{Na}^{+}$as the conservative marine source indicator. The sea-salt component accounts for 61.9 , $65.5,3.5,19.3$, and $2 \%$ of $\mathrm{Cl}^{-}, \mathrm{Mg}^{2+}, \mathrm{Ca}^{2+}, \mathrm{K}^{+}$, and $\mathrm{SO}_{4}^{2-}$, respectively. It is apparent that $\mathrm{Mg}^{2+}$ is mainly $(65.5 \%)$ derived from sea salt, while the sea-salt component of the other species is less than $20 \%$. This finding is also supported by Keene et al. [1986], who considered $\mathrm{Mg}^{2+}$ to be a marine reference element in the study of the non-sea-salt chemical content of marine aerosols.

To explain the increasing nitrate concentration with increasing elevation over the Greenland Ice Sheet, it is necessary to understand the source and formation of nitrate in the atmosphere over Greenland. Although the relationship between measured nitrate concentration in snow and that of $\mathrm{NO}_{y}$ in the ambient atmosphere is far from well understood [Wolff, 1993; Dibb, 1994], it is clear that $\mathrm{NO}_{x}$ and $\mathrm{OH}$ radicals play important roles in the formation of $\mathrm{HNO}_{3}$ [e.g., Logan, 1983; Warneck, 1988]. The major sources of $\mathrm{NO}_{x}$ in the northern hemisphere troposphere include combustion of fossil fuels, lightning at high altitude/low latitude, NO exhalation from soils, and stratospheric inputs [Logan, 1983; Mayewski et al., 1990]. The precursor of nitrate in Greenland snow is believed to be transported through the upper troposphere/lower stratosphere [Finkel et al., 1986; Yang et al., 1995], and the OH radical concentration shows an increase with altitude in high latitudes [Warneck, 1988]. Thus nitrate concentrations in snow would display a trend that increases with elevation over the Greenland Ice Sheet (Figure 2). This finding is also supported by Mulvaney and Wolff [1994], who demonstrated that nitrate concentration increases with increasing elevation over Antarctica. 

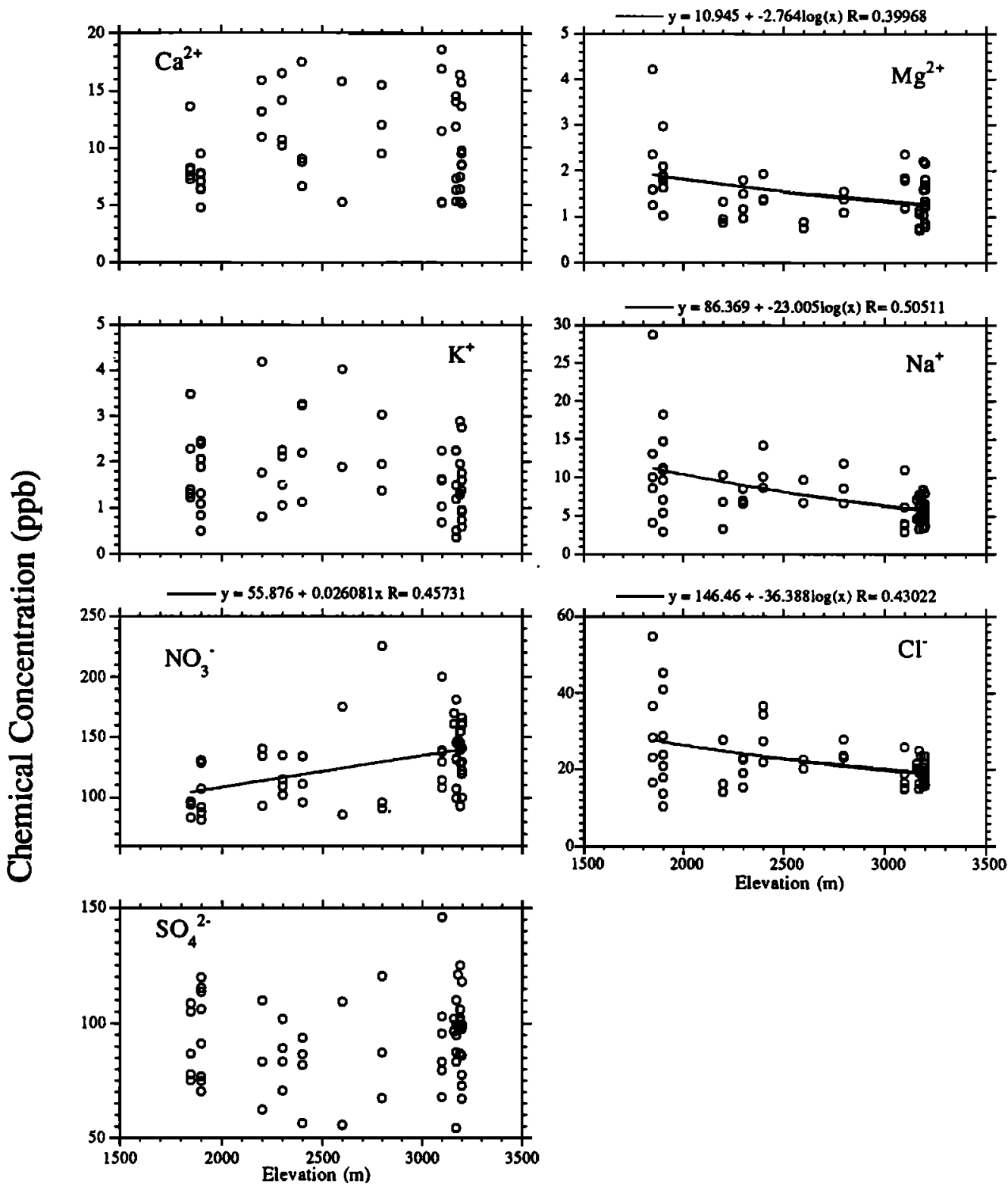

Figure 2. Annual chemical concentration ( $\mathrm{ppb}$ ) of major ions versus elevations above sea level (meters) from snowpits over the Greenland Ice Sheet for the period 1984-1987. (Each point represents individual annual chemical data and the elevation of the snowpit. Data sets from each snowpit vary in terms of the covered period.)

\section{Concentration Versus Accumulation Rate}

The relationship between the concentration of chemical species and snow accumulation rate is important since it can improve our ability to interpret deep ice core chemical data. For instance, changes in concentrations of chemical series from an ice core may be interpreted as (1) changes in atmospheric circulation and source regions, if chemical concentration is independent of snow accumulation rate; (2) changes in snow accumulation rate, if chemical concentration depends on snow accumulation rate. With annual concentration and annual snow accumulation data covering the Greenland Ice Sheet, we investigate the relationship between chemical concentration and snow accumulation rate in central Greenland and over the Greenland Ice Sheet for the period 1984 to 1987 . Using the data from snowpits located in central Greenland, scatterplots of concentration of $\mathrm{Cl}^{-}, \mathrm{NO}_{3}^{-}, \mathrm{SO}_{4}^{2-}, \mathrm{Na}^{+}, \mathrm{K}^{+}, \mathrm{Mg}^{2+}$, and $\mathrm{Ca}^{2+}$ against snow accumulation rate are presented in Figure 3 (open squares). As observed by Yang et al. [1995], there is no predictable relationship between chemical concentration and snow accumulation rate in central Greenland snow.

Chemical species concentration and snow accumulation data from snowpits located in southern and northern Greenland are also plotted on Figure 3 (solid triangles). No clear relationship is observed between the concentration of chemical species and snow accumular tion rate for all chemical species studied if we examine only the data from southern and northern Greenland. However, by considering central, northern and southern 

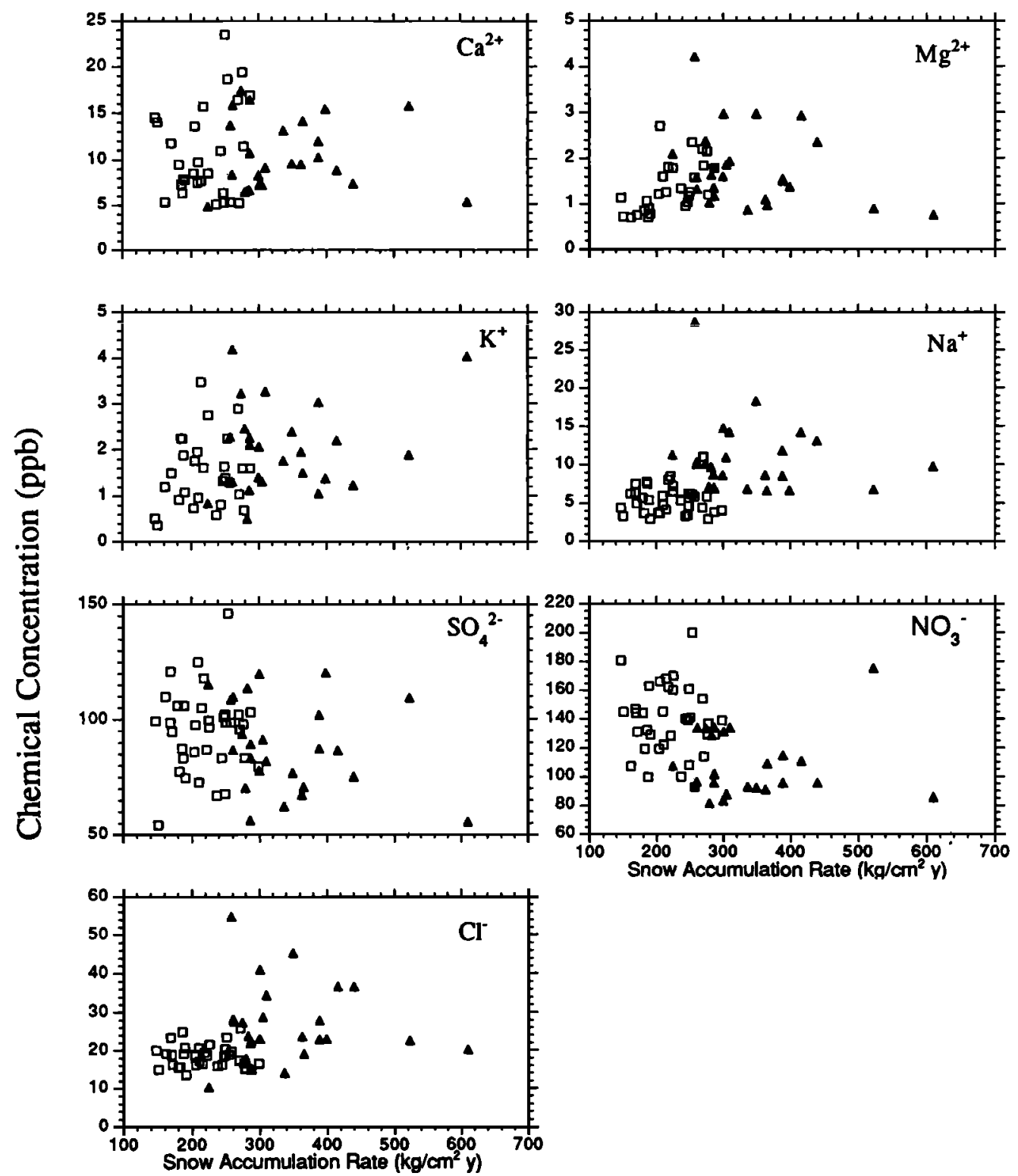

Figure 3. Annual chemical concentration (ppb) of major ions versus snow accumulation rate $\left(\mathrm{kg} \mathrm{m}^{-2} \mathrm{yr}^{-1}\right)$ from snowpits over the Greenland Ice Sheet for the period 1984-1987. (Each point represents individual annual chemical data and the accumulation rate of the snowpit. Open squares represent data collected from snowpits in central Greenland; solid triangles represent data collected from snowpits in southern and northem Greenland.)

data, a decrease in $\mathrm{NO}_{3}^{-}$concentration with increasing snow accumulation rate is apparent as reported by Herron [1982] and Osada and Langway [1993] in Greenland and Mulvaney and Wolf [1994] in the Antarctic. Concentrations of $\mathrm{Cl}^{-}, \mathrm{Na}^{+}$and $\mathrm{Mg}^{2+}$ increase slightly with increasing snow accumulation rate considering all data in Figure 3.

We suggest that the major cause for the increase in $\mathrm{NO}_{3}^{-}$concentration with decrease in snow accumulation rate in Figure 3 is not the accumulation dilution effect reported by Herron [1982], but source and transport pathways. Figure 3 reveals that the mean nitrate concentration in central Greenland (open squares) is higher than the mean nitrate concentration in southern and northern Greenland (solid triangles). As discussed previously for Figure 2, $\mathrm{NO}_{3}^{-}$concentration is higher in central Greenland than in southern and northern Greenland because the source of $\mathrm{NO}_{3}^{-}$is from the upper troposphere/lower stratosphere. A pseudorelationship between chemical concentration and snow accumulation rate could appear (Figure 3) if mixed data, collected from different geographic sites, were put together without considering other factors (e.g., source, transport pathway, and elevation). These pseudorelationships would imply that $\mathrm{Cl}^{-}, \mathrm{Na}^{+}$, and $\mathrm{Mg}^{2+}$ concentrations increase, while $\mathrm{NO}_{3}^{-}$concentrations decrease, with increasing snow accumulation rate over the Greenland Ice Sheet. However, accumulation rate on the Greenland Ice Sheet is characteristically inversely related to elevation. We also learned from Figure 2 that $\mathrm{Cl}^{-}$, 
$\mathrm{Na}^{+}$, and $\mathrm{Mg}^{2+}$ concentration in snow collected from lower elevations of southern and northern Greenland are elevated due to proximity to marine sources. Thus the pseudotrends which show that $\mathrm{Cl}^{-}, \mathrm{Na}^{+}, \mathrm{K}^{+}$, and $\mathrm{Mg}^{2+}$ concentrations increase, while $\mathrm{NO}_{3}^{-}$concentrations decrease, with increasing snow accumulation rate over the Greenland Ice Sheet are actually a reflection of source, transportation pathway, and elevation, rather than accumulation rate. The influence of source, transport pathway, and elevation on chemical concentrations cannot be ignored when investigating the relationship between chemical concentration and snow accumulation rate using geographically mixed data.

Therefore we suggest that, when studying the relationship between chemical concentration and snow accumulation rate, it is important to constrain the investigation to an area over which geographic conditions and sources do not vary significantly. For example, a detailed ice core record covering a period with no major climate and environmental changes may be suited for such study [Legrand and Kirchner, 1990; Yang et al., 1995]. Otherwise, if other influencing factors are not considered, a pseudorelationship could appear between chemical concentration and snow accumulation rate.

\section{Summary}

In this paper we used 24 snowpits from northern, central, and southern Greenland, and covering the same time period, to reevaluate the spatial distribution of chemical species concentration, snow accumulation dependence, and the influence of elevation.

Instead of comparing the multiyear mean values of chemical species [Mayewski et al., 1990], we applied a two-sided $t$-distribution test to determine if annual and seasonal concentrations are statistically the same between northern and southern areas within central Greenland for the years 1984 through 1987.

The relationship between elevation and chemical species concentration was examined in detail using the same data sets. $\mathrm{Cl}^{-}, \mathrm{Na}^{+}$, and $\mathrm{Mg}^{2+}$ decrease with increase in elevation, while nitrate concentration increases with increase in elevation.

The relationship between snow accumulation rate and concentration of chemical species was investigated using two groups of data: central Greenland data and southern and northern Greenland data. None of the chemical species show a predictable relationship to snow accumulation rate within a single group. An apparent relationship between chemical concentration and snow accumulation rate was observed by combining two groups of data. However, when factors such as source and transport pathways are introduced, we conclude that accumulation rate is not a major control on chemical concentrations over the Greenland Ice Sheet.

Acknowledgments. We especially thank J. Dibb for useful discussion and comments on our final version. C. Wake and C. Kingma provided assistance in the field operation, and R. W. Talbot provided useful discussion during manuscript preparation. The line-by-line comments of an anonymous reviewer are greatly appreciated. We are grateful for the assistance of the GISP2 Science Management Office (University of New Hampshire) and the Polar Ice Coring Office (University of Alaska). Support for this work was provided by the National Science Foundation.

\section{References}

Bales, R. C., and E. A. Wolff, Interpreting natural climate signals in ice cores, Eos Trans. $A G U, 76(16)$, Spring Meet. Suppl., 477-483, 1995.

Dansgaard, W., S. J. Johnsen, H. B. Clausen, and N. Gundestrup, Stable isotope glaciology, Medd. Gronl., 197, 2, 1973.

Davidson C. I., J. R. Harrington, M. J. Stephenson, M. J. Small, F. P. Boscoe, and R. E. Gandley, Seasonal variations in sulfate, nitrate and chloride in the Greenland Ice Sheet: Relation to atmospheric concentrations, Atmos. Environ., 23, 2483-2493, 1989.

Dibb, J. E., Overview of field data on the deposition of aerosol-associated species to the surface snow of polar glaciers, in Processes of Chemical Exchange Between the Atmosphere and Polar Snow, NATO ASI Ser., edited by E. Wolff and R. Bales, in press, 1996.

Dibb, J. E., R. W. Talbot, and M. H. Bergin, Soluble acidic species in air and snow at Summit, Greenland, Geophys. Res. Lett., 21, 1627-1630, 1994.

Finkel, R. C., C. C. Langway, and H. B. Clausen, Changes in precipitation chemistry at Dye 3, Greenland, J. Geophys. Res., 91, 9849-9855, 1986.

Herron, M., Impurity sources of $\mathrm{F}^{-}, \mathrm{Cl}^{-}, \mathrm{NO}_{3}^{-}$, and $\mathrm{SO}_{4}^{2-}$ in Greenland and Antarctic precipitation, J. Geophys. Res., 87, 3052-3060, 1982.

Keene W. C., A. A. P. Pszenny, J. N. Galloway, and M. E. Hawley, Sea-salt corrections and interpretation of constituent ratios in marine precipitation, $J$. Geophys. Res., 91, 6647-6658, 1986.

Legrand, M., and R. Delmas, Formation of $\mathrm{HCl}$ in the Antarctic atmosphere, J. Geophys. Res., 93, 7153-7168, 1988.

Legrand, M. R., and S. Kirchner, Origins and variations of nitrate in south polar precipitation, J. Geophys. Res., 95, 3493-3507, 1990.

Logan, J. A., Nitrogen oxides in the troposphere: Global and regional budgets, J. Geophys. Res., 88, 10,785-10,807, 1983.

Mayewski, P. A., and M. R. Legrand, Recent increase in nitrate concentration of Antarctic snow, Nature, 346, 258$260,1990$.

Mayewski, P. A., M. J. Spencer, W. B. Lyons, and M. S. Twickler, Seasonal and spatial trends in south Greenland snow chemistry, Atmos. Environ., 21, 863-869, 1987.

Mayewski, P. A., M. J. Spencer, M. S. Twickler, and S. Whitlow, A glaciochemical survey of the Summit region, Greenland, Ann. Glaciol., 14, 186-190, 1990.

Microsoft Corporation, Microsoft Excel 4.0, Redmond, Washington, 1992.

Mulvaney, R., and E. W. Wolff, Spatial variability of the major chemistry of the Antarctic ice sheet, Ann. Glaciol., 20, 440-447, 1994.

Osada, K., and C. C. Langway, Background levels of formate and other ions in ice cores from inland Greenland, Geophys. Res. Lett., 20, 2647-2650, 1993.

Sigg, A., and A. Neftel, Seasonal variations in hydrogen peroxide in polar ice cores., Ann. Glaciol., 10, 157-162, 1988. Steffensen, J. P., Analysis of the seasonal variation in dust, 
$\mathrm{Cl}^{-}, \mathrm{NO}_{3}^{-}$, and $\mathrm{SO}_{4}^{2-}$ in two central Greenland firn cores, Ann. Glaciol., 10, 171-177, 1988.

Warneck, P., Chemistry of the Natural Atmosphere, 757 pp., Academic, San Diego, Calif., 1988.

Whitlow, S., P. A. Mayewski, and J. Dibb, A comparison of major chemical species seasonal concentration and accumulation at the South Pole and Summit, Greenland, Atmos. Environ., 26A, 2045-2054, 1992.

Wolff, E. A., Nitrate in polar ice, in Ice Core Studies of Global Biogeochemical Cycles, NATO ASI Ser., pp. 195224, Annecy, France, edited by R. J. Delmas, 1995.

Yang, Q., P. A. Mayewski, S. Whitlow, M. Twickler, M. Morrison, R. Talbot, J. Dibb, and E. Linder, Global per- spective of nitrate flux in ice cores, J. Geophys. Res., 100, 5113-5121, 1995.

E. Linder, Mathematics Department, University of New Hampshire, Durham, NH 03824.

P.A. Mayewski, M. Twickler, S. Whitlow, and Q. Yang (corresponding author), Glacier Research Group, Institute for the Study of Earth, Oceans and Space, University of New Hampshire, Durham, NH 03824.

(Received July 31, 1995; revised January 11, 1996; accepted March 5, 1996.) 